\title{
Study on the Development of Household Wastewater Treatment Unit
}

\author{
Ali Hadi Ghawi ${ }^{1}$ \\ 1 University of Al-Qadisiyah, College of Engineering, Department of Civil Engineering, Iraq \\ e-mail: ali.ghawi@qu.edu.iq
}

\begin{abstract}
The cities of Iraq in general and the city of Al Diwaniyah in particular are characterized by the fact that the majority of households use septic tank to dispose of sewage, leading to contamination of ground and surface water and a disturbance to the environment. The objective of this study is to protect the water and soil sources from the risk of pollution, eliminate the process of perfusion and thus, reduce costs, maintain public health, as well as design and implement the proposed purification unit for domestic wastewater treatment. A domestic wastewater treatment unit has been improved to meet the standard specifications for the quality of the effluent wastewater. In this study, a compact non-electric sewage treatment unit was improved and implemented. Treatment is based on an effective modern biological purification process. Experimental verification and analysis of results were performed to demonstrate the improvement of physical and chemical parameters. The performance of the septic tanks-bioreactor gave satisfactory results. The removal efficiencies of total biochemical oxygen demand (BOD), total chemical oxygen demand (COD), total nitrogen $\left(\mathrm{NH}_{4}-\mathrm{N}\right)$, total Kjeldahl nitrogen (TKN) and total suspended solid (TSS) were $96.9 \%, 84.6 \%, 78.8 \%, 79.9 \%$ and $94.3 \%$, respectively.
\end{abstract}

Keyword: septic tank, bioreactor, wastewater, BOD, COD, households

\section{INTRODUCTION}

The central and southern regions of Iraq suffer from the problem of water scarcity and the problem is exacerbated by population growth which will double over a short period of time. The per capita water supply will shrink annually if new water sources are not provided. This, in turn, prompts decision-makers and technicians to seek non-conventional sources of water, including domestic wastewater, for irrigation in environmentally safe ways. It became necessary to use all the available water resources, including low-quality water sources to address these challenges, domestic wastewater is one of these sources. In the central and southern Iraq, the water used to irrigate the house garden consumes a large portion of household water. One of the solutions proposed to contribute to raising the efficiency of domestic water use and alleviate the problem of municipal water shortage, is the reuse of sewage at the household level in the irrigation of the house garden (EPA, 2008, and EPA, 2009).
The septic tanks constitute the most common method in the villages and Iraqi cities to get rid of water at the household level. Wastewater is collected in the septic tank, where a portion of the liquid flows into the surrounding soil through the existing openings and cracks. Wastewater may reach one of the water sources, leading to their contamination (Fayza and Basem 2013). The accumulation of solids in the bottom of the basin leads to the closure of holes in the soil and prevents the leakage of water from the hole and leads to the complete filling, which requires emptying them frequently. The contents of the septic tanks are often discharged to the river, or next to roads or adjacent lands, in this form, posing a danger to the environment and health. Liquid substances may seep into the ground and reach a source of water (Adrados et al., 2014, and Alison et al., 2015).

The existing septic system, located at the entrance to the majority of houses in the city of Al-Diwaniyah, has been a failure for years. Houses had to deal with bad odors, poor effluent quality, high waste disposal costs, water scarcity 
for irrigation of domestic gardens and excessive soil degradation (Izarul et al., 2015, and Singh and Ram 2015). It was a danger to health and the environment and something had to change (Dalahmeh et al., 2014).

The main reasons of this study are the scarcity of available water resources and the need for additional water for irrigation at the household level in rural and urban areas in the city of AlDiwaniyah, the need to implement and develop more efficient and less expensive techniques suitable for wastewater treatment and use in domestic irrigation, reduce the cost of disposal of domestic wastewater, reuse the treated water in the irrigation of domestic gardens and preserve the environment.

The domestic compact wastewater treatment technology studied in this research is characterized by its non-use of electrical energy. The effluent management system has a very low ongoing operational cost (Baker et al., 2015). This system provides an efficient and reliable integrated wastewater treatment solution. Very compressed, these systems are free from any blowers or air diffusers. They do not require any electricity to run, resulting in minimal maintenance and repair costs, lower operating costs and longer decay periods (BIOROCK, 2016, and Rodríguez et al., 2016).

The main objectives of this study were to implementthe sewage treatment unit at the household level to obtain the best quality and quantity of treated water, and study the characteristics of sewage at the domestic level before and after treatment as well as the extent to which it conforms to Iraqi standard specifications. This study was conducted for the purposes of developing solutions to this serious environmental problem by developing the household waste water treatment unit.

\section{MATERIALS AND METHODS}

\section{Development of sewage treatment technology at the household level}

Wastewater (household wastewater consists of black water: origin - toilets, and gray water: origin - kitchen, bathroom, laundry) enters the primary basin (septic tank) of the treatment system. The first phase of Wastewater Treatment is carried out by the septic tank, which is the separation of solids and fat by flotation (formation of a layer of grease) and clarification (suspended solids settle to the bottom of the reservoir by the force of gravity). The solids separated at the bottom of the primary chamber are called "primary sludge". This sludge collapses in time by anaerobic digestion (US EPA, 2016, and Richards et al., 2016).

Most houses in Iraq dispose of wastewater through septic tanks, both in rural areas and urban areas, leading to contamination of the ground and surface water.

The system adopted in these areas for the disposal of domestic sewage is the use of septic tanks, which requires the withdrawal of water periodically at the rate of two to three times per month due to the high level of groundwater and the fact that the soil mud is not permeable. For this reason, we have implemented a sewage treatment unit at the household level and used the treated water to irrigate the house gardens because we have seen the benefit that can be achieved for the families through the implementation of the sewage treatment unit at the household level. The project sought to develop the treatment technology in the target areas to motivate the local community to reuse wastewater (Samia et al. 2017, and Edvard 2017).

The city of Al-Diwaniyah was selected as one of the target areas to motivate citizens to use the domestic unit to treat sewage and reuse it in the irrigation of gardens. The city of Al-Diwaniyah is one of the southern cities of Iraq and the Middle Euphrates region. It is the administrative, economic and political center of Al-Qadisiyah governorate, where all administrative and governmental institutions are located. It is located about 180 $\mathrm{km}$ south of Baghdad (Figure 1 and Figure 2).

\section{Basic design criteria}

The Iraqi National Standards set by the Regulation 25 of 1967 for the design and specifications of wastewater raw and treated sewage from a domestic wastewater treatment unit also the capacity and technological parameters of this study are as follows (Table 1).

The basic design properties of domestic wastewater showed a high concentration of the BOD, COD, and TSS, which necessitated upgrading the treatment system used to obtain agricultural water quality for irrigating the garden without harming public health, or any other element of the environment. 


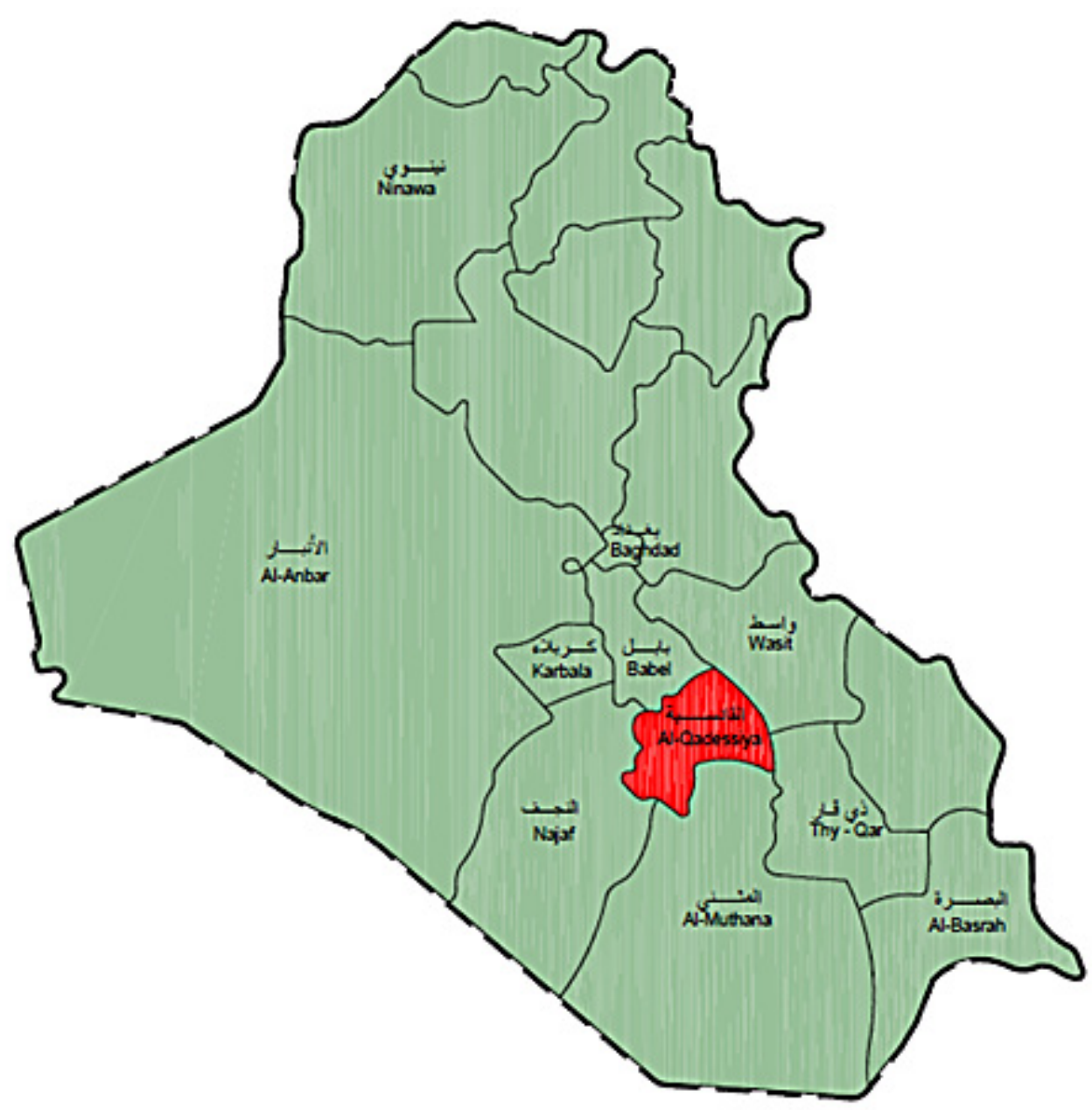

Figure 1. Administrative map of Iraq and the location of Al-Qadisiyah Governorate

\section{Sampling and analytical methods}

Laboratory tests were conducted in the laboratory of the Environment Directorate of AlDiwaniyah Governorate. The parameters measured at the site and in the laboratory included temperature, $\mathrm{pH}, \mathrm{BOD}, \mathrm{COD}, \mathrm{NH}_{4}-\mathrm{N}, \mathrm{TKN}$, and TSS. Samples of raw and treated sewage were collected from the influent of the septic tank and effluent of the bioreactor, respectively, for the purpose of comparing the concentration of the incoming and outgoing wastewater quality from the sewage treatment system. The sewage treatment unit, designed to meet the needs of 6 people, was operated in a residential house in Al-Diwaniyah city in Iraq. Laboratory experiments to measure water quality continued for 12 months from May 2016 to April 2017. These samples were collected daily and analyzed weekly. The analysis was carried out according to the standard method for examination of water and wastewater (APHA, 2005).

\section{RESULTS AND DISCUSSION}

\section{Development of sewage treatment technology at the household level}

The employed processing system was adopted by the BIOROCK for the treatment of sewage at the household and reuse of water in the irrigation of house gardens. The unit consists of two compartments. Initially, the raw sewage (A) enters a primary tank (septic tank, B) to provide separation and the breakdown of organic solids (primary treatment). The sewage then passes through an effluent filter before discharging into the bioreactor unit which incorporates the well-proven aerobic digestion process (secondary treatment) and filtration process (tertiary treatment) (Figure 3) (BIOROCK, 2016). This system is also characterized by the possibility of replacing the septic tank or upgrading the septic tank, as was the case in this research. The septic tank was upgraded by adding a filter in the out- 


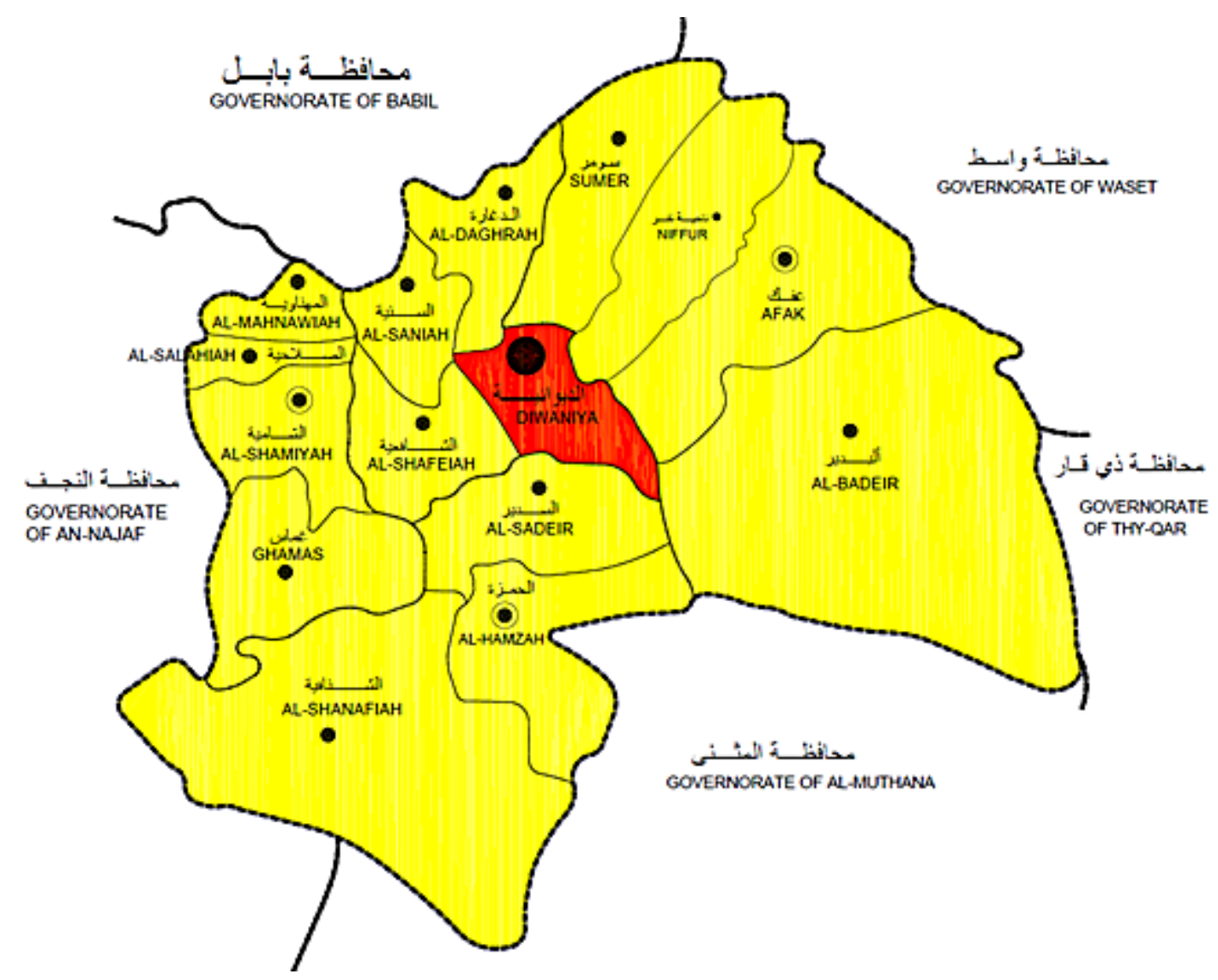

Figure 2. Al-Qadisiyah Governorate map and the location of Al-Diwaniyah City

Table 1. The Iraqi National Standards for the capacity and technological parameters

\begin{tabular}{|c|c|c|}
\hline Characteristic & Value & Unit \\
\hline Capacity in population equivalent & up to 6 & $\mathrm{PE}$ \\
\hline \multicolumn{3}{|c|}{ Primary treatment } \\
\hline Minimum volume of pre-treatment & 2000 & liters \\
\hline Volume per PE & 330 & liters \\
\hline \multicolumn{3}{|c|}{ Secondary treatment } \\
\hline Volume & 1500 & liters \\
\hline Daily volume of wastewater & 150 & liters/day/PE \\
\hline Daily hydraulic load & 0.9 & $\mathrm{~m}^{3} /$ day \\
\hline Organic load per PE & 60 & g.BOD5/PE/day \\
\hline Organic load raw effluent up to & 0.36 & $\mathrm{~kg} \cdot \mathrm{BOD} 5 / \mathrm{day}$ \\
\hline \multicolumn{3}{|c|}{ Specification } \\
\hline Overall length & 2970 & $\mathrm{~mm}$ \\
\hline Length $\times$ width (primary treatment ) & $1595 \times 1140$ & $\mathrm{~mm}$ \\
\hline Secondary treatment area & 0.6362 & $\mathrm{~mm}^{2}$ \\
\hline Overall width & 1415 & $\mathrm{~mm}$ \\
\hline Overall height with ventilation & 2240 & $\mathrm{~mm}$ \\
\hline Pipe diameter & 110 & $\mathrm{~mm}$ \\
\hline
\end{tabular}

Note: The Iraqi National Standards for the design and specifications of wastewater raw and treated sewage from a domestic wastewater treatment unit:

a) Sewage temperature: Min. $-15^{\circ} \mathrm{C}$ (winter), Max. $-30^{\circ} \mathrm{C}$ (summer).

b) Raw sewage characteristics: BOD - $360 \mathrm{mg} / \mathrm{l}$, COD - $460 \mathrm{mg} / \mathrm{l}$, TSS - $360 \mathrm{mg} / \mathrm{l}$, TKN - $40 \mathrm{mg} / \mathrm{l}$, ammonia nitrogen $-30 \mathrm{mg} / \mathrm{l}$, organic nitrogen $-10 \mathrm{mg} / \mathrm{l}$, pH 7 .

c) Treated effluent characteristics (agricultural water quality): $\mathrm{BOD}_{5}-20 \mathrm{mg} / \mathrm{l}, \mathrm{COD}-90 \mathrm{mg} / \mathrm{l}, \mathrm{TSS}-60 \mathrm{mg} / \mathrm{l}$, TKN $-10 \mathrm{mg} / \mathrm{l}, \mathrm{pH} 7$. 


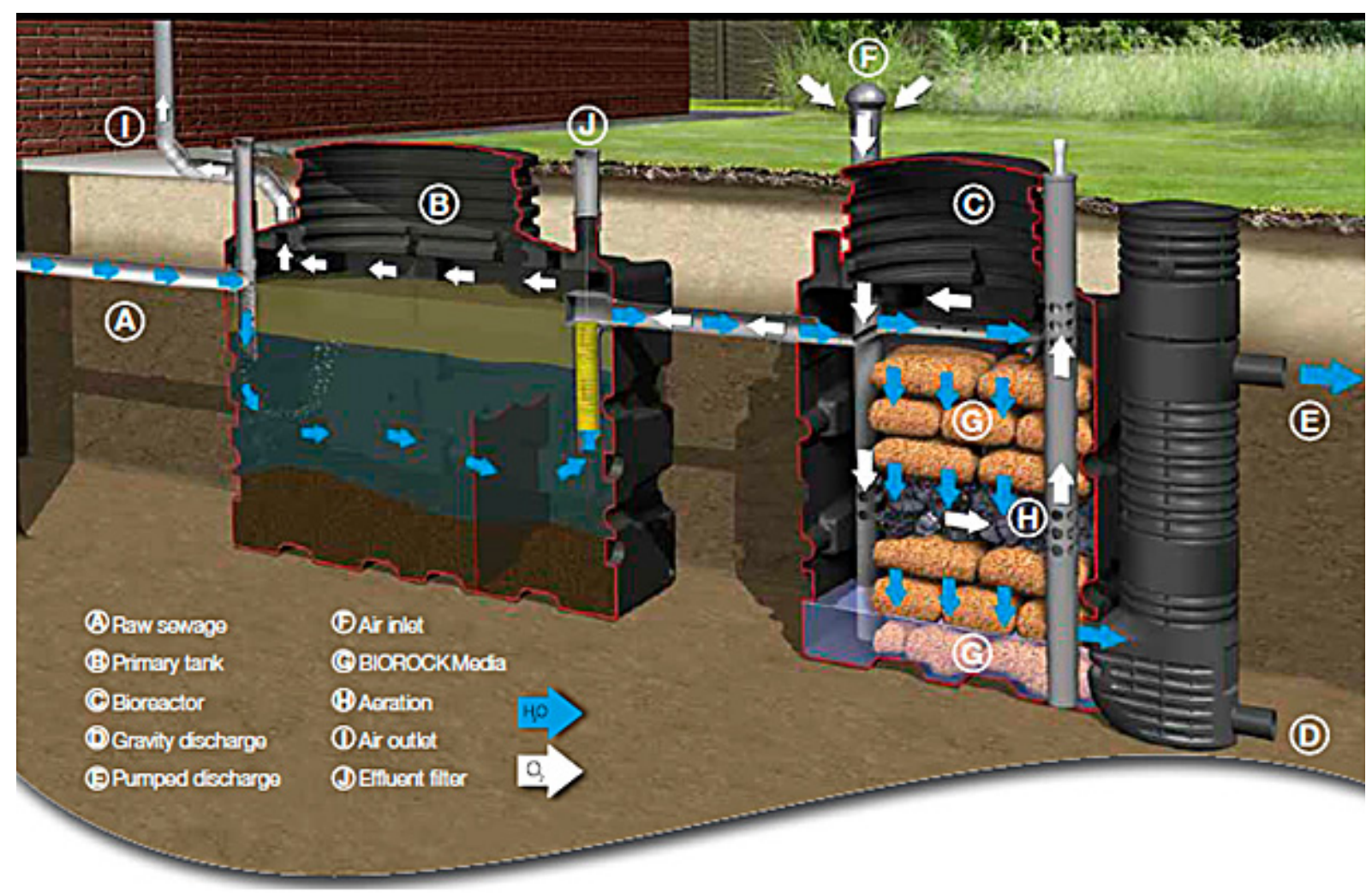

Figure 3. The biorock stages of treatment processes

flow pipe and adding the ventilation system. The sewage then passes into the bioreactor unit. The septic tank is equipped with an efficient effluent filter. This filter again stops suspended solids, fat and other floating materials that enable higher quality of processing.

In this study, the domestic wastewater treatment unit was implemented in a typical $200 \mathrm{~m}^{2}$ house in the center of Al-Diwaniyah city, consisting of a family of 6 members (Figures 4, and 5). The house contains a septic tank and a garden. The septic tank has been connected to the bioreactor, taking into consideration all the directives of Biorock in installing and operating the system.

This system uses a material with huge surface area which allows colonization of the necessary bacteria, a process which is essential for the effective treatment of domestic wastewater. The biological purification process used BIOROCK, which proved to be efficient in the second basin of the domestic wastewater treatment system. The medium is used in the second basin as a carrier material, allowing colonization of the necessary bacteria, a process which is essential for the effective treatment of domestic wastewater. This system consists of three biological filtration stages and one aeration stage (ventilation system).

\section{Suitability assessment for irrigation purpose}

The temperature and $\mathrm{pH}$ of the samples examined ranged from $15^{\circ} \mathrm{C}$ to $30^{\circ} \mathrm{C}$ and from 8 to 7 , respectively. Figures $6,7,8,9$ and 10 show the values of the influent wastewater, the values of the treated wastewater, and the values of the specification limits for the BOD, $\mathrm{COD}, \mathrm{NH}_{4}-\mathrm{N}$, TKN, and TSS, respectively. The results showed that the outflow water are within the Iraqi and international standards, enabling the use in the irrigation of house gardens, taking into account the need of water from the system to disinfection. The wastewater treatment unit did not produce any pollution or odor.

The total biochemical oxygen demand (BOD), total chemical oxygen demand (COD), ammonia nitrogen $\left(\mathrm{NH}_{4}-\mathrm{N}\right)$, total Kjeldahl nitrogen (TKN), and total suspended solid (TSS) efficiency removal were $96.9 \%, 84.6 \%, 78.8 \%, 79.9 \%$ and $94.3 \%$ respectively, which indicated the high efficiency of the treatment unit in removing the contaminants and making the resulting water conform to the specifications. The water from the treatment unit was used to irrigate the house garden.

Local expertise in household wastewater treatment and reuse in agriculture was obtained by implementing a limited-scale wastewater treat- 


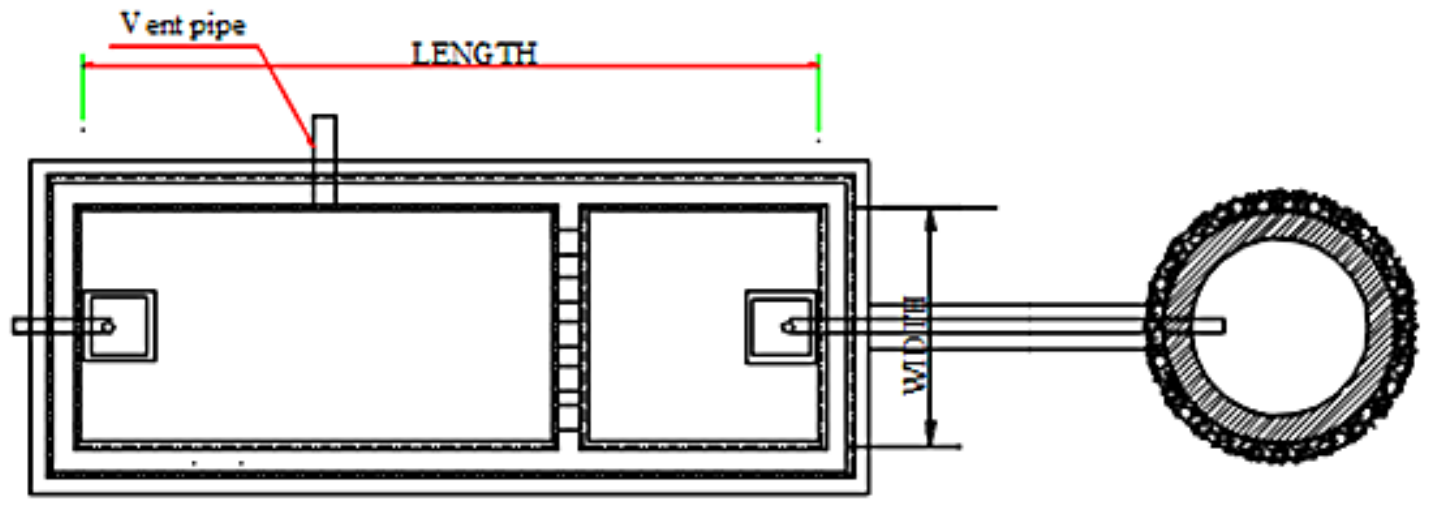

Septic Tank

Bioreactor

Figure 4. The septic tank and bioreactor plan (primary treatment capacity are 2000 liter, and secondary treatment capacity are 1500 liter)

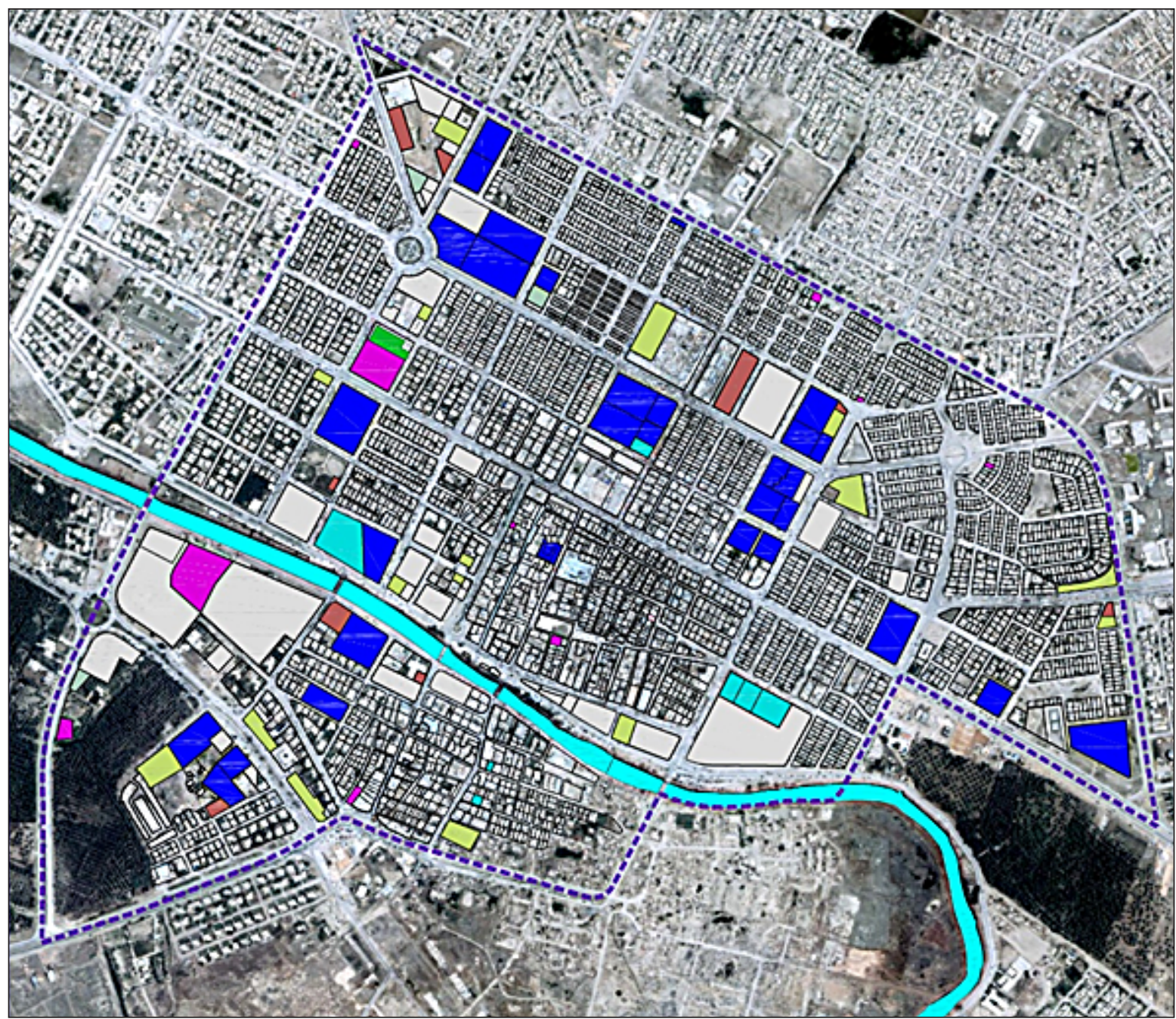

Figure 5. The study area (Al-Diwaniyah City Center)

ment unit. The following average concentration values of samplings from the household wastewater treatment unit outfall have been calculated: - Total biochemical oxygen demand $-8.25 \mathrm{mg} / \mathrm{l}$,
- Total chemical oxygen demand - $60.3 \mathrm{mg} / \mathrm{l}$,

- Total suspended solid - $15.8 \mathrm{mg} / \mathrm{l}$,

- Ammonia nitrogen - $5.4 \mathrm{mg} / \mathrm{l}$,

- Total Kjeldahl nitrogen $-6.91 \mathrm{mg} / \mathrm{l}$. 


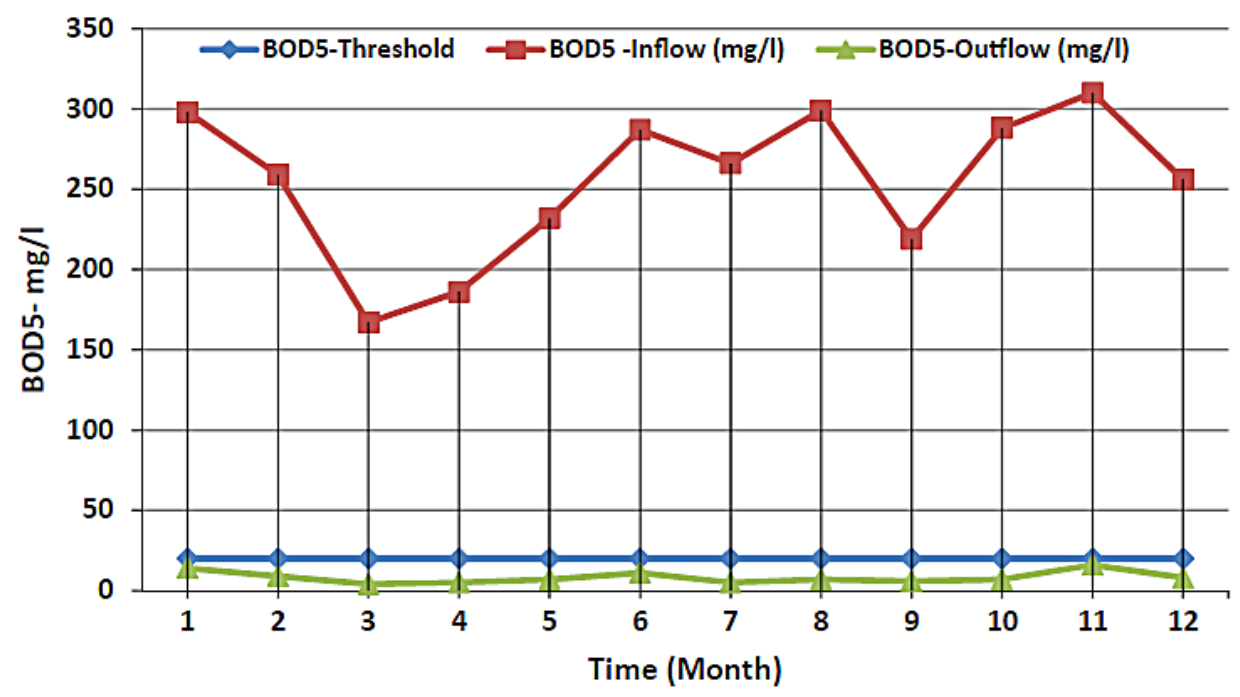

Figure 6. Inflow, outflow, and threshold values of $\mathrm{BOD}_{5}$ in mg/l from May 2016 to April 2017

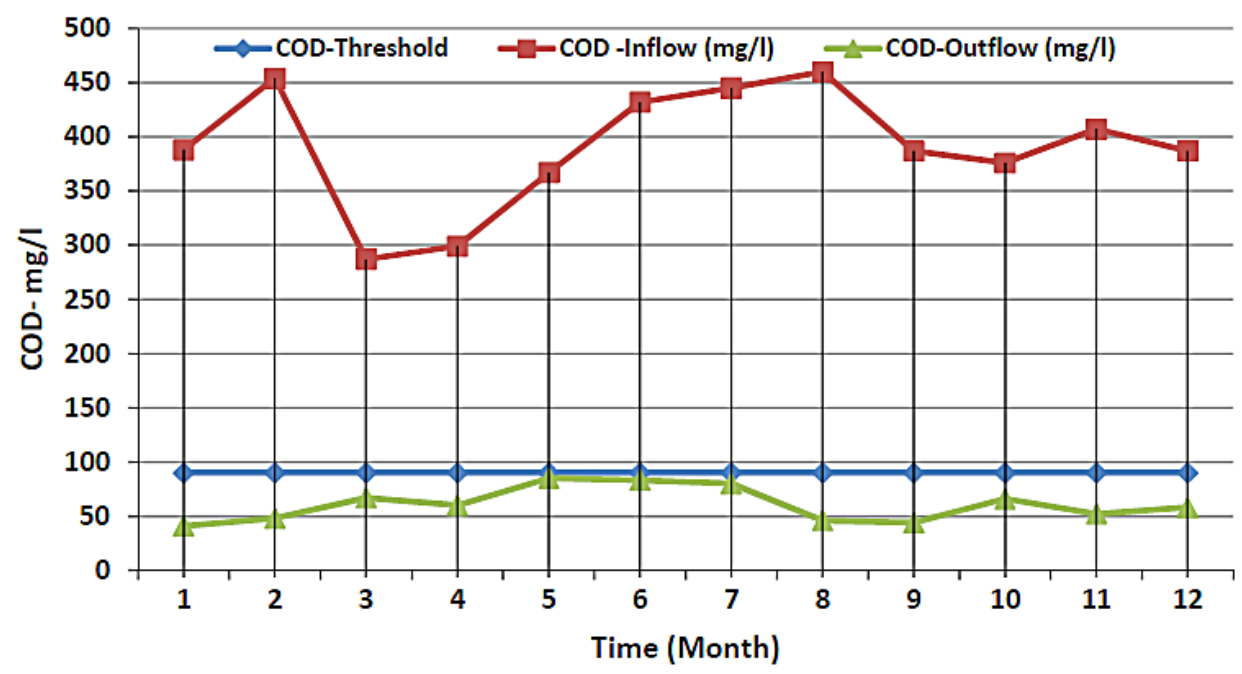

Figure 7. Inflow, outflow, and threshold values of COD in mg/l from May 2016 to April 2017

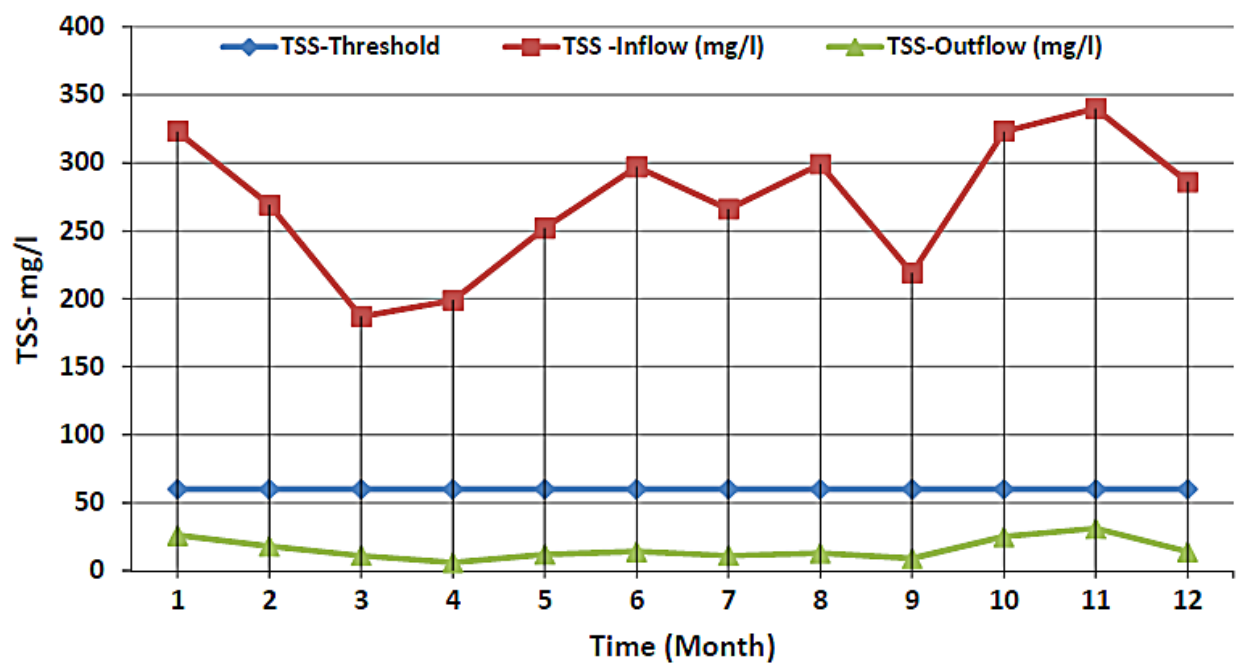

Figure 8. Inflow, outflow, and threshold values of TSS in mg/l from May 2016 to April 2017 
This idea should be spread, developed and made available to specialists and those interested in solving the problem of sanitation in the countryside and cities that contain the septic tanks only, which does not contain a system of sewage network.

\section{CONCLUSION}

Laboratory and field tests were conducted and results analyzed to demonstrate the improvement of the physical and chemical properties of domestic wastewater. Thus, the implementation of septic tank-bioreactor system reduces the demand for water and addresses the problem of water scarcity. The water from the bioreactor can be used for the irrigation purposes in the garden. This type of household waste water treatment unit can be built in an individual house in order to meet their needs. The construction of this system is easy and economical to be implemented and used in the developing countries. The recommended project will reduce the sewage pollution and meet the needs of the next generation.

The BOD, COD, $\mathrm{NH}_{4}-\mathrm{N}, \mathrm{TKN}$ and TSS removal efficiencies were $96.9 \%, 84.6 \%, 78.8 \%$, $79.9 \%$ and $94.3 \%$ respectively. The domestic wastewater treatment unit that has been implemented is well suited for use as a domestic wastewater treatment unit. The specifications of the wastewater resulting from the treatment conformed to the standard Iraqi wastewater standards used in the irrigation of gardens.

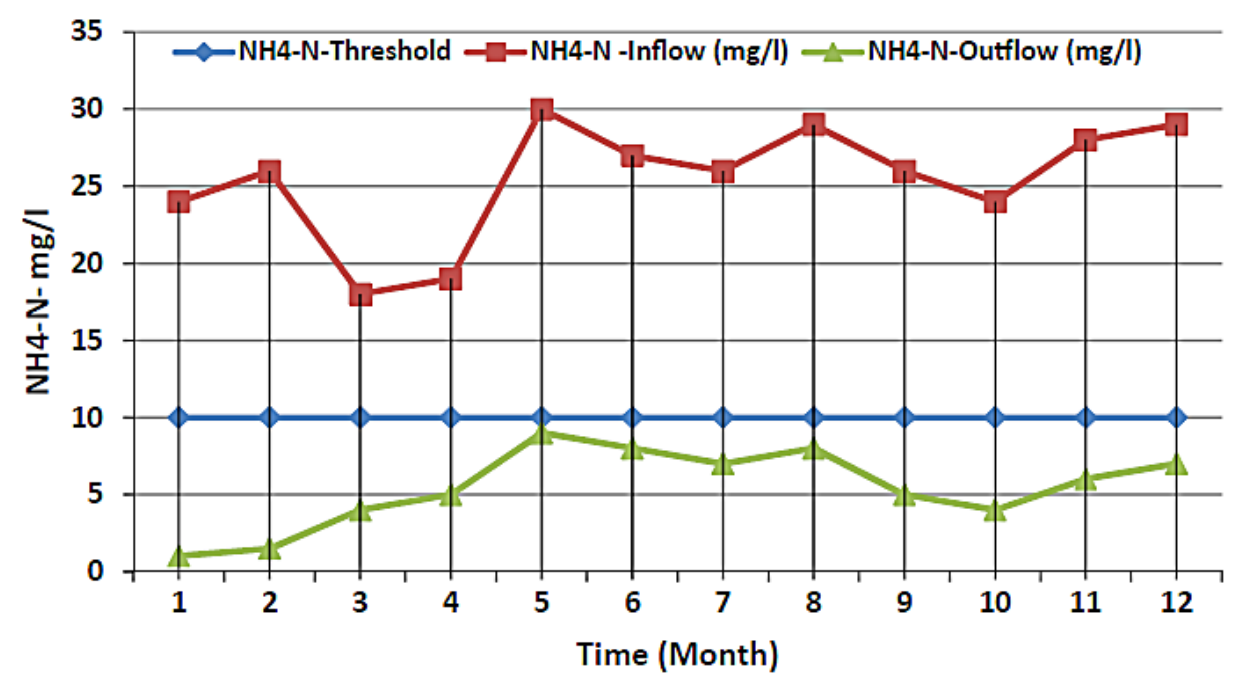

Figure 9. Inflow, outflow, and threshold values of $\mathrm{NH}_{4}-\mathrm{N}$ in mg/l from May 2016 to April 2017

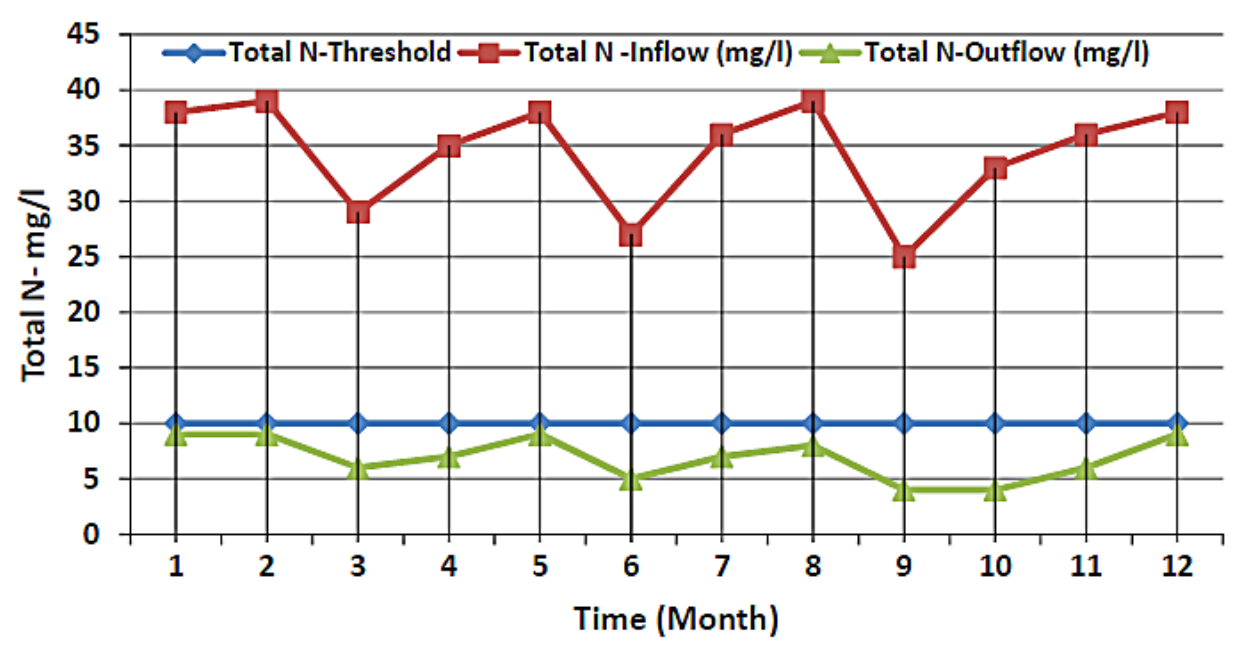

Figure 10. Inflow, outflow, and threshold values of total nitrogen in mg/l from May 2016 to April 2017 


\section{REFERENCES}

1. Adrados B., Sánchez O., Arias C.A., Becares E., Garrido L., Mas J., Brix H., Morató J. 2014. Microbial communities from different types of natural wastewater treatment systems: vertical and horizontal flow constructed wetlands and biofilters. Water Res., 55, 304-312

2. Alison W., Michael B., Troy H., Xiaobo X., Nicholas A.B., Jay G., 2015. Cost-effectiveness of nitrogen mitigation by alternative household wastewater management technologies., Journal of Environmental Management, 150, 344-354

3. APHA, 2005. Standard methods for the examinations of water and wastewater. 21st ed.Washington, DC: American Public Health Association.

4. Baker A., Cumberland S.A., Bradley C., Buckley C., Bridgeman J., 2015. To what extent can portable fluorescence spectroscopy be used in the realtime assessment of microbial water quality? Sci. Total Environ., 532, 14-19.

5. BIOROCK S.À.R.L. 2016. Installation and User Guide for the Biorock septic systems systems. biorock.com

6. Dalahmeh S.S., Jonsson H, Hylander L.D., Hui N., Yu. D., Pell M., 2014. Dynamics and functions of bacterial communities in bark, charcoal and sand filters treating greywater. Water Res., 54, 21-32.

7. Edvard N., 2017. Evaluation of sustainability criteria for small-scale wastewater treatment facilities. the Department of Aquatic Sciences and Assessment, Swedish University of Agricultural Sciences (SLU)UPTEC W 17007.

8. EPA, 2008. Waste Water Discharge Licensing Application Guidance Note. Environmental Protection Agency, Johnstown Castle Estate, Wexford, Ireland.

9. EPA, 2009. Code of Practice: Wastewater Treatment and Disposal Systems Serving Single Houses. Environmental Protection Agency, Johnstown Castle Estate, Wexford, Ireland.
10. Fayza A.N., Basem M., 2013. Treatment of domestic wastewater using conventional and baffled septic tanks. Environmental Technology, 34(16), 2337-2343, http://dx.doi.org/10.1080/09593330.2 013.767285 .

11. Gill L.W., O’Súilleabháin C., Misstear B.D.R., Johnston P., 2009. Comparison of stratified sand filters and percolation trenches for on-site wastewater treatment. Journal of Environmental Engineering, ASCE, January, 8-16.

12. Izarul M., Faisal, Syaifullah M., Takashi O., Kazuaki S. 2015. Use of G3-DHS Bioreactor for Secondary Treatment of Septic Tank Desludging Wastewater. Waste Technology, 3(2), 41-46,

13. Richards, S., Paterson, E., Withers, P.J.A., Stutter, M., 2016. Septic tank discharges as multi-pollutant hotspots in catchment. Sci. Total Environ., 542, 854-863.

14. Rodríguez M.S., Anat D., Yana A.G., Yael G., Yehonatan S., Malka H., Eran F. 2016. Characterization of Biofilm Bacterial Communities in a Vertical Unsaturated-Flow Bioreactor Treating Domestic Greywater. Environ. DOI 10.1007/s40710-016-0162-2.

15. Samia R., Paul J.A.W., Eric P., Colin W. McRoberts, Marc S., 2017. Potential tracers for tracking septic tank effluent discharges in watercourses. Environmental Pollution, 228, 245-255.

16. Singh B., Ram K.Y., 2015. Technological Options for Solid and Liquid Waste Management in Rural Areas Ministry of Drinking Water and Sanitation Swachh Bharat Mission (Gramin) Govt. of India.

17. Sorensen, J.P.R., Lapworth, D.J., Marchant, B.P., Nkhuwa, D.C.W., Pedley, S., Stuart, M.E., Bell, R.A., Chirwa, M., Kabika, J., Liemisa, M., Chibesa, M., 2015. Insitu tryptophan-like fluorescence: a real-time indicator of faecal contamination in drinking water supplies. Water Res., 81, 38-46.

18. US EPA, 2016. Environment Agency - the Sources and Solutions: Wastewater.https://www. epa.gov/nutrientpollution/sources-and-solutions-wastewater. 